\title{
MENINGKATKAN KAPABILITAS PEKERJA SOSIAL MELALUI SUPERVISI PEKERJAAN SOSIAL
}

\author{
OLEH \\ YANA SAFITRI ${ }^{1}$, SANTOSO TRI RAHARJO ${ }^{2}$, RUDI SAPARUDIN DARWIS ${ }^{3}$ \\ 1Mahasiswa Program Studi Kesejahteraan Sosial, Fakultas Ilmu Sosial dan Ilmu Politik, Universitas Padjadajaran \\ 2PPusat Studi Kewirausahaan Sosial, CSR, dan Pengembangan Masyarakat, Fakultas Ilmu Sosial dan Ilmu Politik, Universitas \\ Padjadajaran \\ 3PPusat Studi Kewirausahaan Sosial, CSR, dan Pengembangan Masyarakat, Fakultas Ilmu Sosial dan Ilmu Politik, Universitas \\ Padjadajaran
}

Email:

yanasftr@gmail.com¹, santosotriraharjo@gmail.com², rsdarwis@gmail.com³

\begin{abstract}
ABSTRAK
Pekerja sosial merupakan sebuah profesi yang memberikan kontribusi dalam pemecahan masalah antar hubungan manusia dalam berbagai lingkup dan aspek. Dalam menjalankan tugasnya pekerja sosial juga didasari oleh nilai, etika, dan keterampilan. Pekerja sosial yang banyak berhubungan langsung dengan masyarakat tentu harus memiliki kapabilitas yang baik sehingga dapat diterima dan dipercaya oleh masyarakat. Kapabilitas tersebut bukan hadir bergitu saja, namun hasil dari pembelajaran dan pengalaman. Pekerja sosial tak jarang mengalami kesulitan dan tekanan moral serta membutuhkan bantuan berupa pengetahuan, keterampilan, dan hal-hal lain yang menunjang performanya dalam menjalankan tugas. Supervisi pekerjaan sosial menjadi suatu cara untuk meningkatkan kapabilitas pekerja sosial, yang di dalamnya terdapat bentuk-bentuk supervisi seperti administratif, edukasi, dan suportif. Dengan bentuk supervisi yang dipilih dengan bijak, dan diimpelentasikan dengan baik, maka akan memberikan dampak bagi peningkatan kapabilitas pekerja sosial.
\end{abstract}

\section{Kata Kunci: supervisi, pekerjaan sosial, kapabilitas}

\section{IMPROVING SOCIAL WORKERS CAPABILITY WITH SOCIAL WORK SUPERVISION}

\begin{abstract}
Social worker is a profession that contributes in solving problems between human relations in various spheres and aspects. In performing their duties social workers are also based on values, ethics, and skills. Social workers who deal directly with the community must have good capabilities that can be accepted and trusted by the community. Capability is not gifted, but the result of learning and experience. Social workers often have difficulty and moral pressure and need help in the form of knowledge, skills, and other things that support their performance in
\end{abstract}


carrying out the task. Social work supervision becomes a way of enhancing the capabilities of social workers, in which there are forms of supervision such as administrative, educational, and supportive. With a wisely chosen form of supervision, and well implemented, it will have an impact on increasing the capability of social workers.

\section{Keywords: supervision, social work, capability.}

\section{PENDAHULUAN}

Kapabilitas adalah sesuatu yang harus dimiliki setiap manusia dalam menjalankan pekerjaannya secara professional. Dalam setiap profesi tentu dibutuhkan kemampuan-kemampuan tertentu, ilmu, serta etika. Tak terkecuali dalam profesi pekerja sosial. Menurut Amir (2011:86) menjelaskan bahwa kapabilitas ialah kemampuan mengeksploitasi secara baik sumber daya yang dimiliki dalam diri maupun di dalam organisasi, serta potensi diri untuk menjalankan aktivitas tertentu ataupun serangkaian aktivitas.

Pekerja sosial sendiri berdasarkan International Federation of Social Workers (IFSW) adalah Profesi yang mendorong upaya pemecahan masalah dalam hubungan antar manusia, perubahan sosial, pemberdayaan dan pembebasan manusia, dan memperbaiki masyarakat. Menggunakan teori-teori tentang perilaku manusia dan sistem sosial, pekerjaan sosial melakukan intervensi pada pokok interaksi antara manusia dengan lingkungannya. Prinsip-prinsip hak asasi manusia dan keadilan sosial merupakan hal dasar/fundamental bagi pekerjaan sosial.

Dari pemahaman di atas dapat dipahami bahwa profesi pekerja sosial akan membutuhkan kapabilitas untuk mencapai tujjuan pekerjaannya dan mendapat kepercayaan dari masyarakat. Kapabilitas yang dimiliki oleh pekerja sosial, tidak muncul begitu saja tanpa adanya usaha yang dilakukan. Profesi pekerja sosial yang berhadapan dengan berbagai lingkup manusia, mulai dari individu, kelompok, masyarakat, negara, hingga dunia tentu membutuhkan kemampuan dan pengetahuan yang mumpuni untuk mendukung keberlangsunga praktik. Dalam pelaksanaannya pekerja sosial yang bekerja membantu manusia, akan menghadapi situasi di mana pekerja sosial akan menjadi orang yang membutuhkan bantuan.

Setiap pekerja sosial memiliki pengetahuan dan jam kerja yang berbeda-beda, walau demikian dalam melaksanakan pekerjaannya pekerja sosial tetap harus menunjukan performanya dengan baik. Performa yang baik tersebut didapatakan dari kapabilitas pekerja sosial yang mumpuni. Kapabilitas selain didapatkan dari pengalaman pribadinya, serta pengetahuan yang didapat selama menimba ilmu juga didapatkan dari sesama profesional.

Supervisi pekerjaan sosial merupakan kegiatan dalam pekerjaan sosial yang dapat meningkatkan kapabilitas pekerja sosial. Supervisi dibutuhkan karena kegiatan di dalamnya mencakup komponenkomponen yang dapat menunjang atau meningkatkan kapabilitas pekerja sosial. Pekerja sosial tak jarang mengalama dilema dan kendala dalam menjalankan tugasnya, atau sekadar membutuhkan transfer ilmu dari yang sudah lebih berpengalaman. Maka, proses supervisi dapat menjadi cara untuk mendapatkan itu semua.

Supervisi adalah proses antara sesorang yang disbeut supervisior dan yang lainnya adalah supervisee. Biasanya bertujuan untuk meningktan efektivitas membantu orang tersebut. Supervisi ini di dalamnya mencalup perolehan ketermapilan praktis, penguasan pengetahuan teroritis atau teknis, dan pengembangan professional. (Ferguson dalam Davis: ). Lebih lanjut lagi akan di bahas di dalam bagian selanjutnya bagaimana supervisi berperan dalam peningkatan kapabilitas pekerja sosial.

\section{METODE}

Metode yang digunakan dalam penulisan ini menggunakan kajian literature dari berbagai sumber terkait supervisi pekerjaan sosial dan hasil dari pengetahuan yang didapat selama kegiatan perkuliahan. 


\section{HASIL DAN PEMBAHASAN}

\section{Kapablitas Pekerja Sosial}

Kapabilitas memiliki arti yang hampir sama dengan kompentensi atau kemampuan. Namun pemaknaan kapabilitas tidak sebatas memiliki keterampilan (skill) namun lebih dari itu, yaitu lebih paham secara mendetail sehingga benar benar menguasai kemampuannya dari titik kelemahan hingga cara mengatasinya. Menurut Amir (2011:86) menjelaskan bahwa kapabilitas ialah kemampuan mengeksploitasi secara baik sumber daya yang dimiliki dalam diri maupun di dalam organisasi, serta potensi diri untuk menjalankan aktivitas tertentu ataupun serangkaian aktivitas. Ibarat individu, belum tentu seorang yang memiliki bakat, misalnya pemain piano bisa bermain piano dengan baik. Ini sangat ditentukan dengan bagaimana ia mengembangkannya dengan latihan, dan belajar.

Hal tersebut didukung oleh pendapat Robbin yang mengartikan bahwa kemampuan merupakan sebuah kapasitas yang dimiliki oleh tap-tiap individu untuk melakasanakan tugasnya. Sehingga dapat diambil kesimpulan bahwa kemampuan merupakan suatu penilaian atau ukuran dari apa yang dilakukan oleh orang tersebut. Jadi, kapabilitas yang ada pada pekerja sosial akan membantu pekerja sosial untuk melaksanakan tugasnya.

Pekerja sosial memiliki kemampuan, nilai-nilai, etika dan, prinsip yang harus diterapkan dalam menjalankan praktiknya. Tak jarang pekerja sosial akan menemukan dilemma-dilema yang menganggu dalam pelaksanaan pekerjaannya. Berdasarkan IFSW (2004) berikut adalah professional conduct yang harus diterapkan pekerja sosial:

1. Pekerja sosial diharapkan dapat mengembangkan dan memelihara keterampilan dan kompetensi yang dibutuhkan untuk melakukan pekerjaan mereka,

2. Pekerja sosial seharusnya tidak membiarkan keterampilan mereka digunakan untuk tujuan yang tidak manusiawi, seperti penyiksaan atau terorisme,

3. Pekerja sosial harus bertindak dengan integritas. Ini termasuk tidak menyalahgunakan hubungan kepercayaan dengan orang-orang yang menggunakan layanan mereka, mengenali batas-batas antara kehidupan pribadi dan profesional, dan tidak menyalahgunakan posisi mereka untuk keuntungan atau keuntungan pribadi,

4. Pekerja sosial harus bertindak dalam kaitannya dengan orang-orang yang menggunakan layanan mereka dengan belas kasih, empati dan perhatian,

5. Pekerja sosial seharusnya tidak mensubordinasikan kebutuhan atau kepentingan orang-orang yang menggunakan jasa mereka sesuai kebutuhan atau kepentingan mereka sendiri,

6. Pekerja sosial memiliki kewajiban untuk mengambil langkah-langkah yang diperlukan untuk merawat diri mereka secara profesional dan pribadi di tempat kerja dan di masyarakat, untuk memastikan bahwa mereka dapat memberikan layanan yang sesuai,

7. Pekerja sosial harus menjaga kerahasiaan mengenai informasi tentang orang-orang yang menggunakan layanan mereka. Pengecualian untuk ini hanya dapat dibenarkan atas dasar persyaratan etika yang lebih besar (seperti pelestarian kehidupan),

8. Pekerja sosial perlu mengakui bahwa mereka bertanggung jawab atas tindakan mereka terhadap pengguna layanan mereka, orang-orang yang bekerja dengan mereka, rekan kerja mereka, atasan mereka, asosiasi profesional dan hukum, dan bahwa pertanggungjawaban ini mungkin bertentangan,

9. Pekerja sosial harus bersedia berkolaborasi dengan sekolah kerja sosial untuk mendukung siswa kerja sosial untuk mendapatkan pelatihan praktis yang berkualitas dan pengetahuan praktis terkini,

10. Pekerja sosial harus mendorong dan terlibat dalam debat etis dengan rekan kerja dan 
atasan mereka dan bertanggung jawab untuk membuat keputusan yang berdasarkan etika.

11. Pekerja sosial harus siap untuk menyatakan alasan keputusan mereka berdasarkan pertimbangan etis, dan bertanggung jawab atas pilihan dan tindakan mereka,

12. Pekerja sosial harus bekerja untuk menciptakan kondisi dalam mempekerjakan agen dan di negara mereka di mana asas pernyataan ini dan peraturan nasional mereka sendiri (jika ada) dibahas, dievaluasi dan dijunjung tinggi.

Dari segala macam kapabilitas atau kemampuan yang harus diterapkan oleh pekerja sosial, maka dibutuhkan suatu cara untuk meningkatkan kapabilitasnya. Sehingga, dalam melaksanakan praktik sesuai dengan nilai dan etik yang harus diterapkan dan dapat berbagai pengetahuan, keterampilan, dan dukungan satu sama lain ketika menghadapi beban moral selama menjalankan praktik. Sehingga, supervisi menjadi penting dalam pekerjaan sosial untuk mendukung kapabilitas pekerja sosial dan memberikan kepercayaan kepada klien.

\section{Supervisi Pekerjaan Sosial dalam Meningkatkan Kapabilitas Pekerja Sosial}

Dalam melaksanakan praktiknya pekerja sosial bukan hanya didukung dari pengetahuan yang didapatnya selama mengenyam pendidikan ataupun pengalaman yang sudah ia dapatkan selama melakukan praktik. Namun, juga transfer ilmu dan pengalaman dari para profesional yang sudah lebih lama dan lebih ahli dalam bidang pekerja sosial. Pekerja sosial juga tak jarang mengalami kenadala yang dapat menurunkan peroforma kerja yang mempengaruhi kapabilitas dirinya dalam menjalankan pekerjaannya.

Kapabilitas sebagai pekerja sosial merupakan hal fundamental yaitu sebagai modal untuk memberikan kepercayaan kepada pihak-pihak yang terlibat, termasuk klien. Supervisi pekerjaan sosial merupakan saran untuk meningkatkan kapabilitas pekerja sosial. Supervisi sendiri memiliki banyak pengertian, untuk supervision sendiri berasal dari bahasa latin, yaitu super(over) dan videre(to watch, to see). Dari situ, dapat diartikan bahwa supervisi adalah melihat secara mendalam atu mengontrol untuk mempertahankan atau meningkatkan kualitas.

NASW, 2013 menjelaskan: Untuk tujuan standar supervisi ini, supervisi profesional didefinisikan sebagai hubungan antara supervisor dan supervisee di mana tanggung jawab dan akuntabilitas untuk pengembangan kompetensi, sikap, dan praktik etis berlangsung. Supervisor adala yang bertanggung jawab untuk memberikan arahan kepada supervisee, yang menerapkan teori kerja sosial, Pengetahuan standar, keterampilan, kompetensi, dan Konten etis yang berlaku dalam pengaturan praktik. Supervisor dan supervisee keduanya berbagi tanggung jawab untuk menjalankan peran mereka dalam hal ini proses kolaboratif.

Jadi,supervisi dalam pekerjaan sosial melibatkan mereka para supervisor yang melakukan supervisi kepada para supervisee yang melakukan praktik pekerjaan sosial. Dalam melakukan supervisi, supervisior hanya memeberikan arahan bukan langsung mendikte supervisee untuk melakukan tindakan tertentu dan membatasi kemampuannya, dan juga bukan langsung menintervensi klien yang sedang ditangani oleh supervisee, tapi tetap supervisee yang bersentuhan langsung dengan klien.

Ada banyak model pengawasan yang dijelaskan dalam literatur, mulai dari tradisional, model otoriter untuk lebih kolaboratif Model. Model supervisi berbeda penekanan, dalam berbagai tingkat, pada klien, supervisor, supervisi, atau konteks di dimana pengawasan dilakukan. Idealnya, Supervisor dan supervisee menggunakan proses kolaboratif ketika model pengawasan dipilih.

Namun, pada akhirnya akhirnya merupakan tanggung jawabnya adalah supervisor untuk memilih model yang paling sesuai pengembangan profesional supervisee. Hubungan pengawasan dibangun 
berdasarkan kepercayaan, Kerahasiaan, dukungan, dan empatik Pengalaman. Kualitas lainnya yang melekat pada Hubungan supervisor mencakup konstruktif umpan balik, keamanan, rasa hormat, dan perawatan diri.

Supervisi juga merupakan bentuk pelayananan tidak langsung yang memberikan fungsi untuk para supervisee, yaitu:

- Fungsi administratif,

- Fungsi edukasi,

- Fungsi Suportif(dukungan moral).

Fungsi administratif dari supervisior kepada supervisee meliputi:

1. Staf rekrutmen dan seleksi

2. Menggambarkan dan menempatkan pekerja

3. Perencanaan kerja

4. Tugas kerja

5. Delegasi kerja

6. Monitoring, review, dan evaluasi kerja

7. Koordinasi kerja

8. Fungsi komunikasi

9. Pengawas sebagai advokat

10. Pengawas sebagai penyangga administratif

11. Pengawas sebagai agen perubahan.

Sementara untuk fungsi edukasi adalah proses transfer ilmu dari supervisor kepada supervisee, di sini dapat dilakukan susuai jadwal atau sesuai kebutuhan supervisee ketika membutuhkan pengetahuan untuk melaksanakan praktiknya. Untuk fungsi suportif adalah pemberian dukungan moral kepada supervisee, dalam melaksanakan tugasnya, karena tak jarang pekerja sosial menemukan kendala dilemma etis atau beban moral dan emosional dalam melaksanakna praktiknya. Dengan dukungan moral ini dapat menjadi sumber dukungan dan semangat pekerja sosial dalam untuk menghadapi Kendal yang ditemui di lapangan.

Fungsi-fungsi tersebut dapat digambarkan dengans ingkat melalui gambar berikut ini:

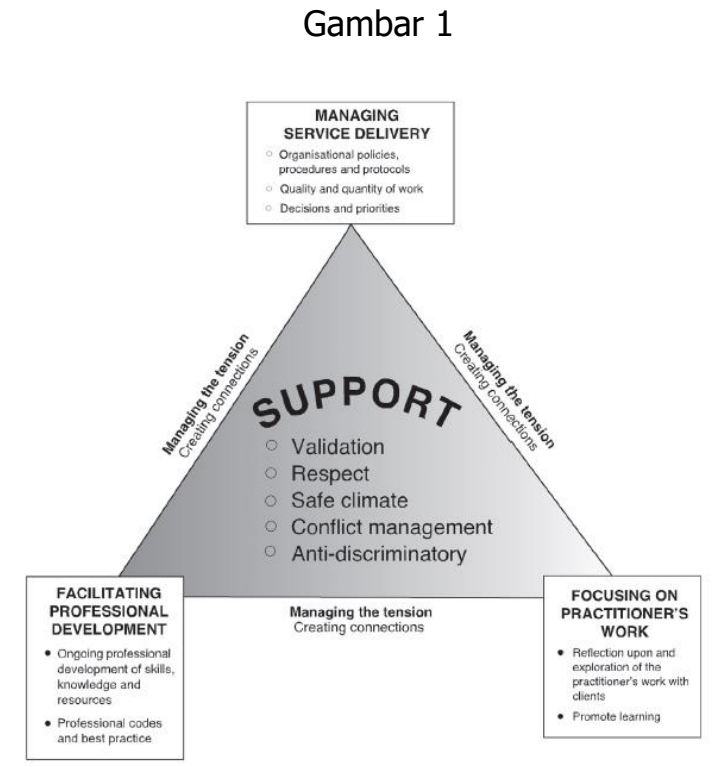

Sumber: Davyz, dkk.

Dari fungsi-fungsi tersebut dengan implementasi yang baik dari organisasi-organisasi pelayanan sosial, dan terciptanya hubungan yang kolaboratif dalam proses supervisi tentunya akan menciptakan kapabiltas pekerja sosial yang mumpuni yang dapat memberikan kompetensi yang baik dalam melaksankan pekerjaannya. Studi menunjukkan bahwa sebagian besar supervisi mengekspresikan kepuasan dengan pengawasan Mereka menerima dan bahwa supervisor melakukan pekerjaan yang lebih efektif sebagai hasil pelatihan formal.

\section{SIMPULAN DAN SARAN}

\section{Simpulan}

Pekerja sosial membutuhkan supervisi untuk meningkatkan kapabilitasnya dalam melaksankan praktik pekerjaan sosial. Kapabilitas dibutuhkan untuk menumbuhkan kepercayaan dari pihak-pihak yang terlibat dalam praktik pekerjaan sosial, termasuk klien yang ditangani oleh pekerja sosial. Di dalam supervisi terdapat bentuk-bentuk model supervisi, dan kegiatan yang menunjang kapabilitas pekerja sosial, yang di dalamnya meliputi administratif, edukatif dan suportif. 


\section{Saran}

Kegiatan supervisi merupakan kegiatan penting yang harus dimiliki dengan baik oleh setiap lembaga dan organisasi pelayanan sosial. Penulis memberikan rekomendasi bagi tiap lembaga pelayanan sosial untuk mulai memperhatikan pentingnya supervisi karena dapat meningkatakan kapabilitas pekerja sosial. Bukan semata pekerja sosial melakukan pekerjaannya dengan perspektif dan ilmu yang ia miliki sendiri, namun perlu adanya transfer ilmu, dan dukungan-dukungan dari supervisor yang ada dalam supervisi.

\section{DAFTAR PUSTAKA}

Kadushin, Alfred. \& Harkness, Danie. 2002. Supervision in Social Work. New York: Columbia University Press.

Davyz, Allyson. \& Beddoe Liz. 2010. Best Practice in Professional Supervision. Philadelphia: Jessica Kingsley Publisher.

National Association of Social Workers. 2013. Best Practice in Social Work Supervision. Washington, D.C.: NASW

Anonim. BAB II. Melalui, <http://digilib.unila.ac.id/11660/20> (2205-17)

IFSW. Statement of Ethical Principles. Melalui, <http://ifsw.org/policies/statement-ofethical-principles/> (22-05-17)

IFSW. Global Defiition of Social Work. Melalui, $<$ http://ifsw.org/policies/definition-ofsocial-work/> (22-05-17)

Raharjo, ST. 2015. Assessment untuk Praktik Pekerjaan Sosial dan Kesejahteraan Sosial. Bandung: Unpad Press
2015. Dasar Pengetahuan Pekerjaan Sosial. Bandung: Unpad Press. 2015. Keterampilan Pekerjaan Sosial: Dasar-dasar. Bandung, Unpad Press. 